\title{
THE ANALYSIS OF THE PROLIFERATIVE ACTIVITY OF CELLS ON MICROPARTICLES OBTAINED FROM DECELLULARIZED LIVER AND KIDNEY TISSUE
}

\author{
M.M. Bobroval, 2, L.A. Safonova ${ }^{1,2}$, O.I. Agapova', A.E. Efimov', I.I. Agapov ${ }^{1}$ \\ ' Laboratory of Bionanotechnology, V.I. Shumakov National Medical Research Center \\ of Transplantology and Artificial Organs of the Ministry of Healthcare of the Russian Federation, Moscow, \\ Russian Federation \\ ${ }^{2}$ Biological faculty, Lomonosov Moscow State University, Moscow, Russian Federation
}

\begin{abstract}
Aim. To develop the protocols for liver and kidney tissue decellularization, and to develop an analysis of the proliferative activity of human $\mathrm{Hep}-\mathrm{G}_{2}$ hepatocarcinoma cells on various carriers. Materials and methods. Decellularization of the liver and kidneys was performed by perfusion of detergent solutions with gradually increasing concentrations of Triton X-100 (1,2 and 3\%). A histological analysis of the obtained samples was performed, and the method of optical and scanning electron microscopy was used to study the obtained samples. The proliferative activity of human $\mathrm{Hep}-\mathrm{G}_{2}$ hepatocarcinoma cells was studied on the obtained samples of decellularized liver and kidney tissue. Results. Decellularization of the organ does not lead to changes in the specific structure of the tissue matrix. Microparticles with an average size of $200 \mu \mathrm{m}$ were made from their decellularized matrix of liver and kidney tissues. The level of proliferative activity of human $\mathrm{Hep}-\mathrm{G}_{2}$ hepatocarcinoma cells cultured on microparticles from a decellularized liver was significantly higher than on microparticles from a decellularized kidney. Conclusion. The decellularized matrix retains the native three-dimensional structure of the tissue. The level of cell proliferative activity is significantly higher on microparticles from the decellularized liver, which confirms the preservation of the specificity of the extracellular matrix of the tissue after the process of decellularization.
\end{abstract}

Key words: decellularization, extracellular matrix, microparticles.

\section{АНАЛИЗ ПРОЛИФЕРАТИВНОЙ АКТИВНОСТИ КАЕТОК В МИКРОЧАСТИЦАХ, ПОАУЧЕННЫХ ИЗ АЕЦЕААЮЛЯРИЗОВАННОЙ ТКАНИ ПЕЧЕНИ И ПОЧКИ}

\author{
М.М. Боброва ${ }^{1,2}$, Л.А. Сафонова ${ }^{1,2}$, О.И. Агапова ${ }^{1}$, А.Е. Ефимов", И.И. Агапов \\ ' ^аборатория бионанотехнологий ФГБУ «Национальный меАицинский исслеАовательский \\ центр трансп^антологии и искусственных органов имени академика В.И. Шумакова» \\ Минзарава России, Москва, Российская Фелерация \\ ${ }^{2}$ Биологический фракультет ФГБОУ ВО «Московский государственный университет \\ имени М.В. Аомоносова», Москва, Российская Фелерация
}

\begin{abstract}
Цель. Разработка протоколов децеллюляризации ткани печени и почек, а также анализ пролиферативной активности клеток гепатокарциномы человека Нер- $\mathrm{G}_{2}$ на различных носителях. Материалы и методы. Децеллюляризация печени и почек была произведена путем перфузии растворов детергентов с постепенно возрастающими концентрациями Тритона X-100 (1, 2 и 3\%). Был произведен гистологический анализ полученных образцов, использован метод оптической и сканирующей электронной микроскопии для исследования полученных образцов. Исследована пролиферативная активность клеток гепатокарциномы человека Нер- $\mathrm{G}_{2}$ на полученных образцах децеллюляризованной ткани печени и почки. Результаты. Децеллюляризация органа не приводит к изменениям в специфической структуре матрикса ткани. Микрочастицы со средним размером 200 мкм были изготовлены из децеллюляризованного матрикса тканей печени и почки. Уровень пролиферативной активности клеток гепатокарциномы человека Нер- $\mathrm{G}_{2}$,
\end{abstract}

For correspondence: Agapov Igor Ivanovich. Address: 1, Shchukinskaya str., Moscow, 123182, Russian Federation.

Tel. (985) 231-60-42. E-mail: igor_agapov@mail.ru

Для корреспонденции: Агапов Игорь Иванович. Адрес: 123182, Москва, ул. Щукинская, д. 1.

Тел. (985) 231-60-42. E-mail: igor_agapov@mail.ru 
культивированных на микрочастицах из децеллюляризованной печени, был существенно выше, чем на микрочастицах из децеллюляризованной почки. Заключение. Децеллюляризованный матрикс сохраняет нативную трехмерную структуру ткани. Уровень пролиферативной активности клеток существенно выше на микрочастицах из децеллюляризованной печени, что подтверждает сохранность специфичности межклеточного матрикса ткани после процесса децеллюляризации.

Ключевые слова: децеллюляризация, внеклеточный матрикс, микрочастицьы.

\section{INTRODUCTION}

Orthotopic organs transplantation is the most common treatment of many severe diseases [1]. Artificial grafts are used to maintain functions of patients while waiting for a suitable donor organ. But this treatment can't be an alternative to permanent orthotopic transplantation. Chronic acute lack of donor organs available for transplantation, the long transplantation list, the urgency of the operation leads to searching for alternative, more cost-effective and efficient strategies for liver and kidneys transplantation $[2,3]$.

The main problem of tissue engineering is the creation of complex functional structures and vascularization of the graft. Furthermore, used to create synthetic tissue matrix biomaterials are not able to promote the ligandmediated tissue regeneration due to absence of specific ligands for the respective cells [4].

Organs decellularization is one of the promising techniques in regenerative medicine for fabricating transplants of various organs and scaffolds for cell culture [5]. Cellular components are removed from the tissues by decellularization, while extracellular matrix is retained. The resulting decellularized organ transplant preserves three-dimensional structure, the vascular network, the biological activity of the extracellular matrix [6]. The decellularized three-dimensional matrix provides native microenvironment for cultured cells and can enhance cell adhesion, proliferation and differentiation [7]. Such transplant matrix can be recellularized with functional cells or progenitor cells of a particular organ. According to the literature the success of decellularized matrices implantation is associate with the specific molecular interactions between protein structures of the extracellular matrix [8]. Matrix proteins, which comprise the bulk of these materials is evolutionarily conserved. This structure can explain the lack of immune response in the recipient's body after transplantation [9].

Decellularization method application for producing three-dimensional native transplants is limited by number of challenges, including the correct selection of the organ's donor, optimization of decellularization protocol, the selection of recellularization technique of a received transplant and the selection of the cell population for correct interaction between cells and the extracellular matrix [10]. The goal of our investigation was to develop protocols for liver and kidneys decellularization, and to analyze the proliferative activity of Hep-G2 cells cultured on various carries.

\section{METHODS}

\section{Animals}

The experiments were conducted on male Wistar rats (250-350 g). All animal care procedures were conducted in accordance with the principles and norms of humane treatment of animals (European Convention ET/S 129 (1986) and ESC Directive 86/609 on Experimental Animals). Before surgery the rats were injected with heparin, to reduce thrombosis, and $30 \mathrm{~min}$ later they were given an angioprotector, and before the operation the rats were anesthetized for general parenteral anesthesia. All drugs were given intraperitoneally.

\section{Liver decellularization}

The rat livers were decellularized using a method described in our previous study [11]. The portal vein was cannulated. The liver was first perfused by sodium phosphate buffer, at a rate of $150 \mathrm{ml} / \mathrm{h}$ to free the organ from blood, using a peristaltic pump. Liver was decellularized by sequential perfusion using three solutions containing sodium phosphate buffer $(\mathrm{pH}=7.4), 500 \mathrm{ml}$, $0.1 \%$ sodium dodecyl sulfate, the first solution was contained $1 \%$ Triton $X-100$, the second $-2 \%$ Triton X-100, and the third $-3 \%$ Triton $X-100$. The perfusion rate was $150 \mathrm{ml} / \mathrm{h}$. Detergent solutions were eliminated from the liver using sodium phosphate buffer.

\section{Kidney decellularization}

For kidneys decellularization the aorta was cannulated and organs were perfused with peristaltic pump. The kidneys were first perfused by sodium phosphate buffer, at a rate of $400 \mathrm{ml} / \mathrm{h}$ to free the organ from blood. Kidneys were decellularized by sequential perfusion using three solutions containing sodium phosphate buffer $(\mathrm{pH}=7.4), 500 \mathrm{ml}, 0.1 \%$ sodium dodecyl sulfate, the first solution was contained $1 \%$ Triton X-100, the second $-2 \%$ Triton $X-100$, and the third $-3 \%$ Triton $\mathrm{X}-100$. The perfusion rate was $400 \mathrm{ml} / \mathrm{h}$. Detergents in solutions were eliminated from the kidneys using sodium phosphate buffer.

\section{Histological analysis of decellularized matrix}

For analysis of decellularized matrixes structure tissue specimens were fixed with $4 \%$ formaldehyde, dehydrated and embedded in paraffin. Then $14 \mu \mathrm{m}$ thick slices were made with a microtome Leica CM 1900 UV 
(Leica Microsystems GmbH, Austria). Then staining of specimens was performed with hematoxylin-eosin to identify nucleated cells. These stained specimens were embedded in Canada balsam. To analyze the structure of the matrixes an optical microscope Zeiss Axiovert 25 Sarl (Jena, Germany) with camera Axio Cam HRC (Carl Zeiss, Germany) were used.

\section{Fabrication of microparticles from decellularized matrixes}

The microparticles were fabricated using a method described in our previous study [11]. For microparticle producing decellularized matrix was milled using surgical scissors, and was transferred to a tube made up to 15 $\mathrm{ml}$ of $15 \%$ glycerol solution in sodium phosphate buffer $(\mathrm{pH}=7.4)$. Glycerol solution was used as a cryoprotector. Solution was incubated for 20 minutes, and then centrifuged for 10 minutes at $8500 \mathrm{~g}$. The precipitate was ground in liquid nitrogen using a pre-cooled pestle and mortar for 5 minutes. Obtained particles were transferred to a clean pre-chilled tube and the volume adjusted to 25 $\mathrm{ml}$ by $70 \%$ ethanol under stirring. The resulting particles suspension was centrifuged for 10 minutes at $450 \mathrm{~g}$, the supernatant was removed and $25 \mathrm{ml}$ of $70 \%$ ethanol was added to precipitate and resuspended. The procedure was repeated three times. Obtained suspension contained microparticles of decellularized liver or kidney matrix with an average size $200 \mu \mathrm{m}$. The process of particles fractionation was monitored visually using optical microscope Zeiss Axiovert 25 Sarl (Jena, Germany).

\section{Analysis of the matrixes' structure by scanning electron microscopy}

Decellularized tissue specimens for scanning electron microscopy were fixed with $2.5 \%$ glutaraldehyde in phosphate-buffered saline $(\mathrm{pH}=7.4)$. Further fixed specimens were incubated for 5 minutes in phosphatebuffered saline, the procedure was repeated 5 times. Then specimens were dehydrated with increasing concentrations of ethanol (10-30-50-70-96\%) by incubating 30 minutes in each, and transferred to acetone. The specimens were dried by HCP-2 critical point dryer (Hitachi Ltd., Japan). The dried specimens were coated with gold layer,20 nm thick, inside the argon atmosphere at ion current $6 \mathrm{~mA}$ and pressure $0.1 \mathrm{~mm} \mathrm{Hg}$ using IonCoaterIB-3 (EikoEngineering, Mito, Japan), then analyzed by a scanning electron microscope Camscan S2 (CambridgeInstruments, Cambridge, UK). Microscope resolution was 10 $\mathrm{nm}$, the operating voltage $-20 \mathrm{kV}$. Images were obtained using the software «MicroCapture» (SMA, Russia).

\section{Analysis of cell proliferative activity on decellularized matrix}

To study the proliferative activity was used 3 different substrates: 1) particles prepared from decellularized liver, 2) particles prepared from decellularized kidney, 3) Cytodex $^{\circledR} 3$ microcarriers beads were used as a control. $100 \mu \mathrm{l}$ of DMEM culture medium with 20 $\mathrm{mg} / \mathrm{ml}$ of HEPES, $10 \%$ fetal bovine serum and $40 \mu \mathrm{g} /$ $\mathrm{ml}$ of gentamicin, which containing $5.3 \times 10^{4}$ of human hepatocarcinoma cell culture Hep-G2 were added to 50 $\mu \mathrm{l}$ of carriers. Cells were incubated at $37{ }^{\circ} \mathrm{C}, 5 \% \mathrm{CO}_{2}$ under stirring for 9 days.

Evaluation of proliferative activity was performed by MTT assay at 3, 6 and 9 days of the experiment [12]. $50 \mu$ fivefold solution of 3-[4,5-dimethylthiazol-2-yl]2,5-difeniltetrazolium bromide (MTT), which is a substrate for mitochondrial dehydrogenases functioning in living cells, were added to each tube and incubated at $37{ }^{\circ} \mathrm{C}$ in $5 \% \mathrm{CO}_{2}$ for 4 hours, resulted in the formation of dark blue crystals of formazan. Then tubes were centrifuged for 15 minutes at $885 \mathrm{~g}$. The supernatant was removed and the formazan precipitate dissolved in dimethyl sulfoxide. The staining solution was transferred to a 96-well plate. Optical density value was detected at $540 \mathrm{~nm}$ by immunoassay analyzer Picon (Picon, Russia).

\section{Statistical analysis}

The all results were statistically processed by ANOVA, $p=0.05$ being taken as a significant point.

\section{RESULTS}

\section{Tissue decellularization}

To perform these study specimens of decellularized liver tissue were obtained by perfusion of the portal vein with solutions of sequential increasing concentrations of Triton X-100. Flow rate of solutions through the vein was $150 \mathrm{ml} / \mathrm{h}$. Each obtained specimen of decellularized tissue was a translucent matrix of rat liver, which released from cells (Fig. 1, a). The same specimens of decellularized kidneys were obtained by perfusing through the aorta which was performed with solutions of sequential increasing concentrations of Triton X-100, as in the case of decellularized liver. Flow rate of solutions was 400 $\mathrm{ml} / \mathrm{h}$. Specimens of decellularized kidney was a pale yellow matrix without cells, which didn't lose organ's shape (Fig. 1, b).

\section{Histological analysis of decellularized matrix}

To identify the structure of the decellularized liver and kidneys specimens of their matrixes were prepared for histological examination, stained with hematoxylineosin. Analysis of received specimens showed that after the perfusion a natural three-dimensional architecture 

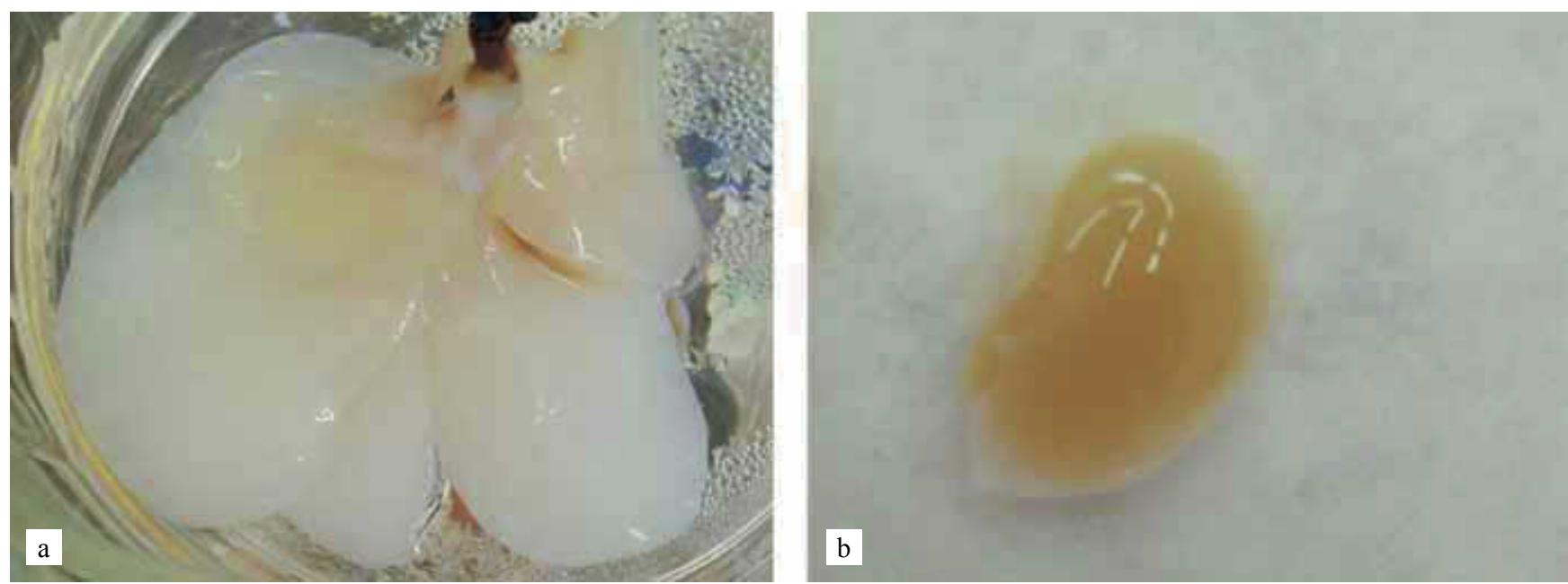

Fig. 1. Decellularized liver (a) and kidney (b) by perfusing solutions with sequential increasing concentration of Triton X-100

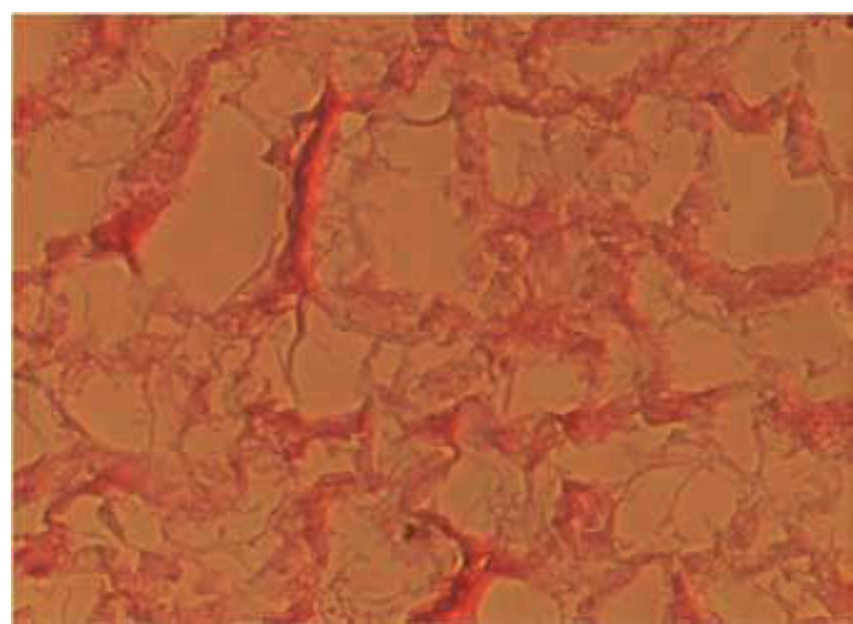

Fig. 2. Images of the histological specimen of the liver extracellular matrix. Hematoxylin-eosin staining. Retained specific structure of liver matrix. Histology revealed no nuclei $(\times 200$, phase contrast)

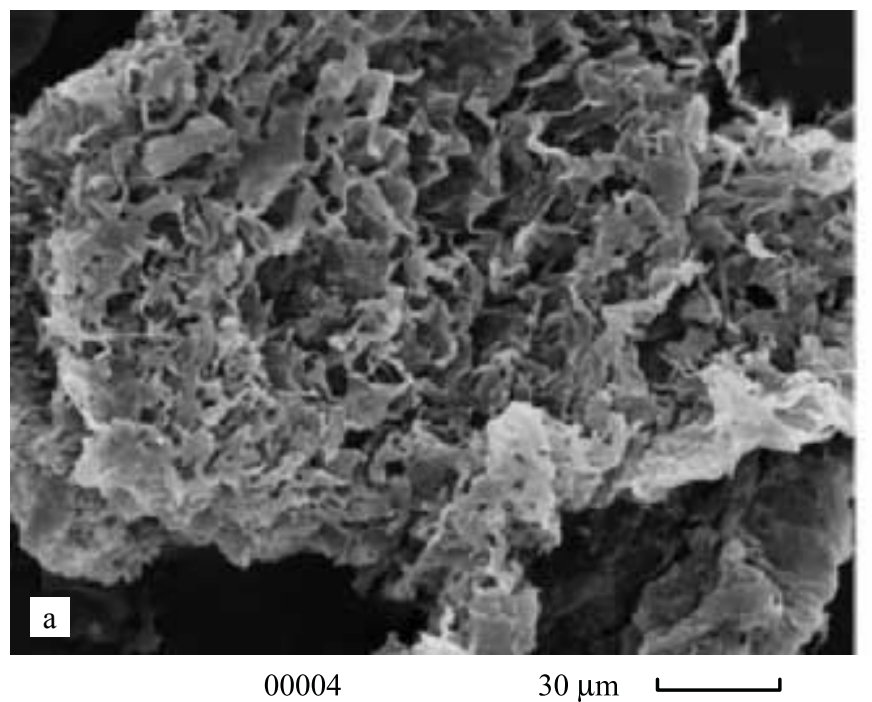

Fig. 3. SEM images of decellularized liver (a) and kidney (b) and structural matrix was remain. Histological evaluation showed no nuclear or cytoplasmic staining in decellularized matrix. Stained liver decellularized matrix shows at Fig. 2, data of kidney decellularization were similar and not shown.

\section{Analysis of the matrixes' structure by scanning electron microscopy}

For analyzing the matrixes structure by scanning electron microscopy microparticles with a mean size of 200 $\mu \mathrm{m}$ were produced from obtained decellularized tissues. It was found that the liver matrix has an extensive system of pores, the cells were not identified (Fig. 3, a). Image analysis of decellularized kidney tissue revealed no cells and the matrix had a dense structure (Fig. 3, b).

\section{Analysis of cells proliferative activity}

Evaluation of proliferative activity of the cells was assessed by the example of human hepatocellular carci-

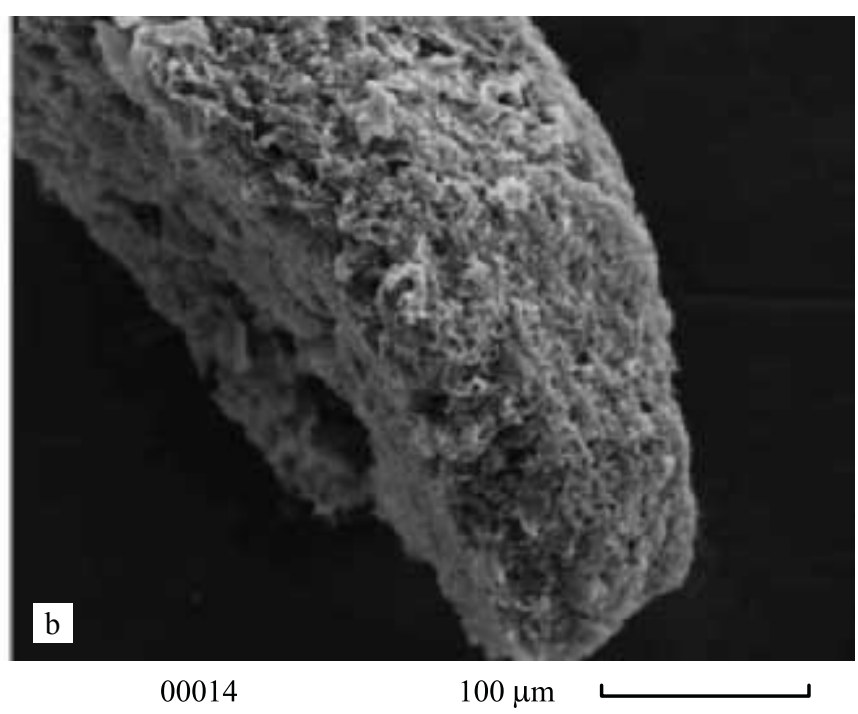




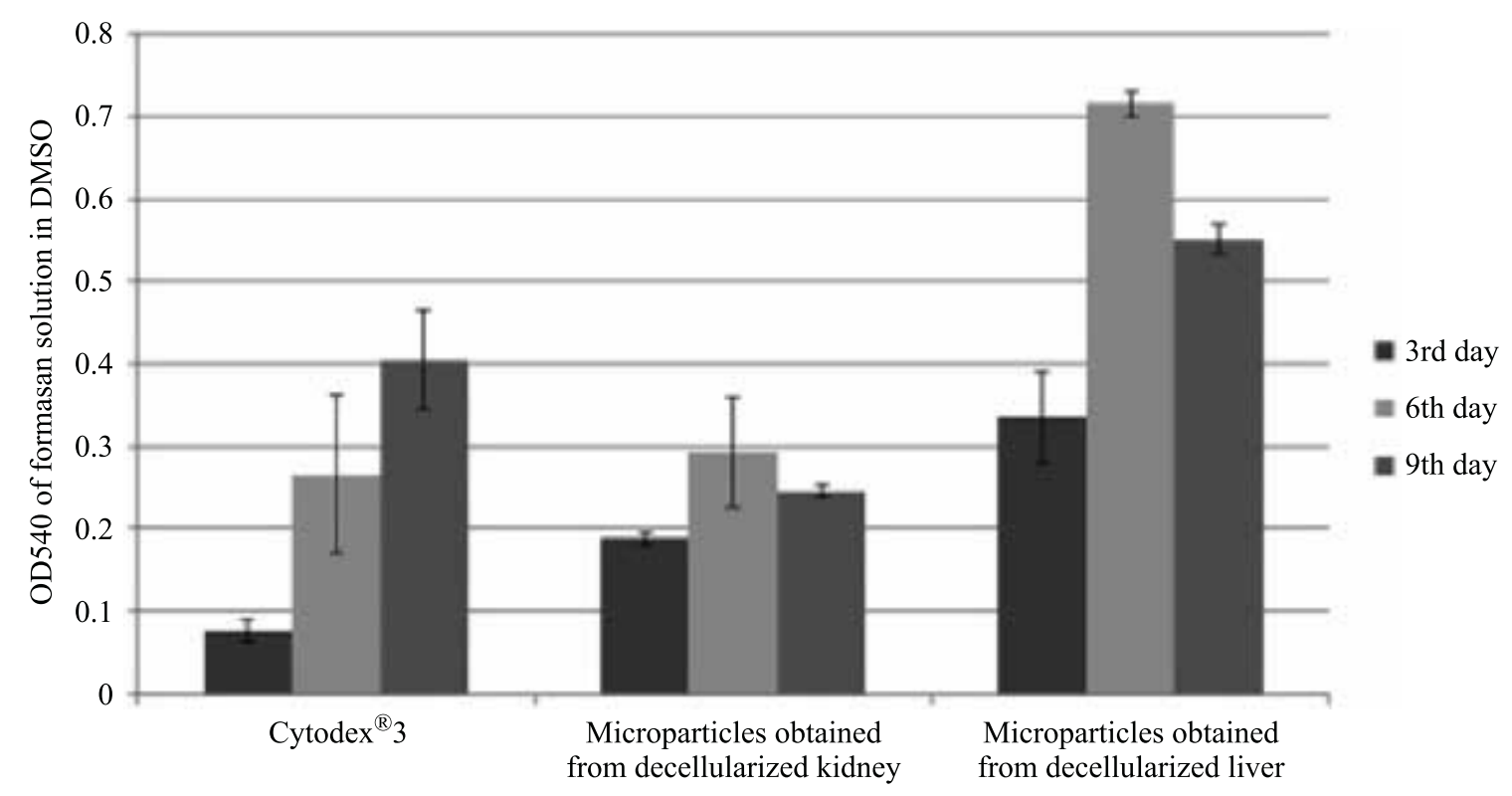

Fig. 4. Data of the proliferative activity of Hep-G2 cell culture on various carriers at 3rd, 6th and 9th day of experiment: 1 - Cytodex ${ }^{\circledR} 3 ; 2$ - decellularized kidney with Triton X-100 solution; 3 - decellularized liver with Triton X-100 solution. Specify values for the standard deviation of 5 independent experiments

noma cell line Hep- $\mathrm{G}_{2}$. As a positive control commercial microcarriers Cytodex ${ }^{\circledR} 3$ were used, which are microspheres with an average diameter of $175 \mu \mathrm{m}$, coated with denatured collagen. Evaluation of cell proliferative activity was conducted by MTT assay. The experiment was performed for nine days, were three control measuring point. The data present in histograms (Fig. 4).

The highest cells proliferative activity was estimated at microparticles from liver matrix decellularized with Triton X-100 solution. The level of cell proliferation activity at decellularized kidney microparticles was comparable to the level of cells proliferative activity at $\mathrm{Cy}$ todex ${ }^{\circledR} 3$ microcarriers at 6 and 9 days of the experiment.

\section{DISCUSSION}

Decellularization of tissues or organs is one of the perspective strategies for regenerative medicine and tissue engineering $[13,14]$. After decellularization the cellular material and most part of the major histocompatibility complex are removed from tissue [15] with minimal changes in the composition and with maintaining the biological activity of extracellular matrix [16]. Selection of decellularization method for each organ depends on many factors such as the density of the organ, the population of cells, the thickness of the organ composition [17]. Dense tissues of highly differentiated organs require anterograde or retrograde perfusion to more effectively remove cells [18]. It is also necessary to choose the optimal composition of the perfused solution. Earlier in our study, we developed the optimal protocol of liver decellularization with portal vein perfusion solutions containing Triton X-100. In this study, decellularized kidney matrix was obtained by perfusing the aorta with a Triton X-100 solution [19]. As the detergent Triton $\mathrm{X}-100$ was chosen, because it is a non-ionic detergent which disrupts lipid-lipid and lipid-protein interactions, but leaves intact protein-protein interactions [20]. Triton $\mathrm{X}-100$ is described in the literature as detergent capable remove cellular material with minimal change in the biochemical composition of the matrix, its structures and ligands, as well as the biological activities of the components of the extracellular matrix. Gradual increase of the Triton X-100 solution concentration in the perfused solution used for softer removing cellular material [21].

To confirm the success of the organs decellularization histological specimens of the liver and kidneys extracellular matrix were obtained. Hematoxylin-eosin staining of tissues showed no nuclear, indicating the success of the selected decellularization techniques. Moreover, preservation of the natural structure of the matrix and its three-dimensional architecture were identified in analyzing specimens. Deccellularized matrix forms the necessary microenvironment for cells that affects on its morphology, differentiation and proliferation [22].

Integrity of the three-dimensional ultrastructure of the extracellular matrix and the absence of cells was confirmed by scanning electron microscopy. The liver extracellular matrix is characterized by an extensive system of pores, an average size of $20 \mu \mathrm{m}$. Such porous structure is optimal for adhesion of hepatocytes [23]. Kidney matrix has a dense structure, less friable, due to the function and structure of the organ.

For analyzing the cells proliferative activity $\mathrm{Hep}-\mathrm{G}_{2}$ cells were incubated at microparticles of decellularized tissues. During the experiment the cells proliferative activity on microparticles of decellularized liver and kidney 
marixes were compared with cells proliferative activity on Cytodex ${ }^{\circledR} 3$. In result the highest cells proliferative activity was estimated at liver matrix microparticles which was decellularized with Triton X-100 solution. The higher proliferative activity may be connected with differences in the qualitative and quantitative composition of the liver matrix as compared to the kidneys matrix. Technique and concentrations of Triton X-100 were used in our research can contribute the release of previously screened sites for receptors binding, which promote the adhesion of hepatocytes, and it's becoming available to the cells [24]. Furthermore, a specific hepatocyte growth factors associated with components of the extracellular matrix can be released by perfusion with $3 \%$ Triton X-100 solution [25]. Also, differences in cell proliferative activity on the liver and kidneys matrixes can be explained by the unique topology of the matrix surface and the ligands located thereon that provides adhesion, proliferation, differentiation and tissue-specific cell migration [26].

\section{CONCLUSIONS}

Decellularization of tissues and organs is the successful technology for the creation of support materials for tissue engineering and regenerative medicine. The possibility of using decellularization method is very high: from the creation of tissue, blood vessels, specific microcarriers for cells to whole body with highly specific functions, such as the heart.

In this investigation were prepared decellularized liver and kidneys matrixes by perfusion of solutions with increasing concentrations of the detergent Triton $\mathrm{X}-100$. Histological evaluation of decellularized tissues doesn't identify nuclei, which indicate a complete removal of the cells from the matrix. Analysis by scanning electron microscopy confirmed the absence of a cellular component in decellularized matrix as well as retained three-dimensional architecture of organs. Proliferative activity of Hep- $\mathrm{G}_{2}$ cells at liver matrix which was decellularized with increasing concentrations of Triton $\mathrm{X}-100$ solutions was significantly higher than the cell proliferative activity at decellularized kidney matrix, which proves the liver specificity of extracellular matrix after decellularization procedure. Thus, it was shown that the decellularization method retains the structural and biochemical characteristics of the extracellular matrix of organ after cells removal.

\section{Acknowledgements}

This work was supported by the Russian Scientific Foundation (Project No. 17-75-10098).

\section{REFERENCES}

1. Nari GA, Cid M, Comín R et al. Preparation of a threedimensional extracellular matrix by decellularization of rabbit livers. Rev Esp Enferm Dig. 2013; 105 (3): 138143.

2. Ye JS, Stoltz JF, Isla N, Liu Y, Yin YF, Zhang L. An approach to preparing decellularized whole liver organ scaffold in rat. Biomed Mater Eng. 2015; 25: 159-166.

3. Nakayama KH, Batchelder CA, Lee GE, Tarantal AF. Decellularized rhesus monkey kidney as a three-dimensional scaffold for renal tissue engineering. Tissue Eng Part A. 2010; 16 (7): 2207-2216.

4. Lutolf MP, Hubbell JA. Synthetic biomaterials as instructive extracellular microenvironments for morphogenesis in tissue engineering. Nat Biotechnol. 2005; 23 (1): 47-55.

5. Lee JS; Cho $S W$. Liver tissue engineering: Recent advances in the development of a bio-artificial liver. Biotechnol. Bioprocess. Eng. 2012; 17 (3): 427-438.

6. Soto-Gutierrez A, Zhang L, Medberry $C$ et al. A Whole-Organ regenerative medicine approach for liver replacement. Tissue Eng Part C Methods. 2011; 17 (6): 677-686.

7. Nelson CM, Bissell MJ. Of extracellular matrix, scaffolds, and signaling: tissue architecture regulates development, homeostasis, and cancer. Annu Rev Cell Dev Biol. 2006; 22: 287-309.

8. Barnes CA, Brison J, Michel $R$ et al. The surface molecular functionality of decellularized extracellular matrices. Biomaterials. 2011; 32 (1): 137-143.

9. Hussein KH, Park KM, Teotia PK. Fabrication of a biodegradable xenoantigen-free rat liver scaffold for potential drug screening applications. Transplantation Proc. 2013; 45 (8): 3092-3096.

10. Badylak SF, Freytes DO, Gilbert TW. Extracellular matrix as a biological scaffold material: structure and functional. Acta Biomater. 2009; 5 (1): 1-13.

11. Bobrova MM, Safonova LA, Agapova OI, Krasheninnikov ME, Shagidulin My, Agapov II. Liver tissue decellularization as a promising porous scaffold processing technology for tissue engineering and regenerative medicine. Sovrem. Technol Med. 2015; 7 (4): 6-13.

12. Mossman T. Rapid colorometric assay for cellular growth and survival: application to proliferation and cytotoxicity assays. J Immunol Methods. 1983; 65 (1-2): 55-63.

13. Baptista PM, Siddiqui MM, Lozier G, Rodriquez SR, Atala A, Soker $S$. The use of whole organ decellularization for the generation of a vascularized liver organoid. Hepatology. 2011; 53 (2): 604-617.

14. Shupe T, Williams M, Brown A, Willenberg B, Petersen $B E$. Method of the decellularization of intact rat liver. Organogenesis. 2010; 6 (2): 134-136.

15. Macchiarini P, Jungebluth P, Go T et al. Clinical transplantation of a tissue-engineered airway. Lancet. 2008; 372 (9655): 2023-2029.

16. Zhou P, Lessa N, Estrada D et al. Decellularized liver matrix as a carrier for the transplantation of human fetal 
and primary hepatocytes in Mice. Liver Transpl. 2011; 17 (14): 418-427.

17. Crapo PM, Gilbert TW, Badylak SF. An overview of tissue and whole organ decellularization processes. Biomaterials. 2011; 32 (12): 3233-3243.

18. Arenas-Herrera JE, Ko IK, Atala A, Yoo JJ. Decellularization for whole organ bioengineering. Biomed Mater. 2013; 8 (1): 014106.

19. Wang Y, Bao J, Wu $Q$ et al. Method for perfusion decellularization of porcine whole liver and kidney for use as a scaffold for clinical-scale bioengineering engrafts. Xenotransplantation. 2015; 22 (1): 48-61.

20. Gilbert TW, Sellaro TL, Badylak SF. Decellularization of tissues and organs. Biomaterials. 2006; 27 (19): 3675-3683.

21. Ren H, Shi X, Tao L et al. Evaluation of two decellularization methods in the development of an organ decellularized rat liver scaffold. Liver Int. 2013; 33 (3): 448-458.

22. Pei M, Li JT, Shoukry M, Zhang Y. A review of decellularized stem cell matrix: a novel cell expansion system for cartilage tissue engineering. European Cell Mater. 2011; 22: 333-343.

23. Uygun BE, Soto-Gutierrez A, Yagi H et al. Organ reengineering through development of a transplantable recellularized liver graft using decellularized liver matrix. Nat Med. 2010; 16 (7): 814-820.

24. Canning P, Tan L, Chu K, Lee SW, Gray NS, Bullock AN. Structural mechanisms determining inhibition of the collagen receptor DDR1 by selective and multi-targeted type II kinase inhibitors. J Mol Biol. 2014; 426 (13): 2457-2470.

25. Londono R, Badylak SF. Biological scaffolds for regenerative medicine: mechanisms of in vivo remodeling. Ann Biomed Eng. 2015; 43 (3): 577-592.

26. Shirakigawa N, Ijima H, Takei T. Decellularized liver as a practical scaffold with a vascular network template for liver tissue engineering. J Biosci Bioeng. 2012; 114 (5): 546-551.

Статья поступила в редакциию 8.10.2018 2. The article was submitted to the journal on 8.10.2018 